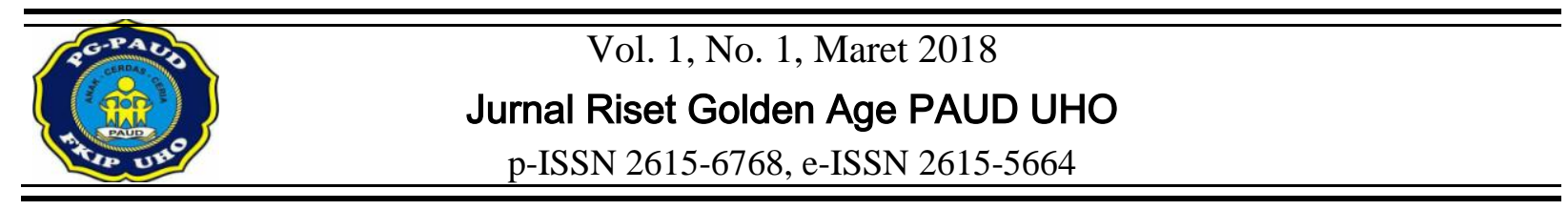

\title{
MENINGKATKAN KEMAMPUAN MOTORIK HALUS ANAK MELALUI KEGIATAN MEWARNAI, MENGGUNTING DAN MENEMPEL (3M) DI TK MEKAR INDAH KOTA KENDARI
}

\author{
Lisdarlia $^{\text {1), Salwiah }}{ }^{2)}$ \\ ${ }^{1}$ Alumni Jurusan PG-PAUD, Universitas Halu Oleo. Jln. H.E.A Mokodompit, Kendari 93232, \\ Indonesia. \\ ${ }^{2}$ Dosen Jurusan PG-PAUD, Universitas Halu Oleo. Jln. H.E.A Mokodompit, Kendari 93232, \\ Indonesia.
}

\begin{abstract}
Abstrak
Penelitian ini bertujuan untuk meningkatkan kemampuan motorik halus anak melalui kegiatan Mewarnai, Menggunting dan Menempel (3M) di TK Mekar Indah Kota Kendari. Jenis penelitian ini adalah Penelitian Tindakan Kelas (PTK) yang dilaksanakan dalam dua siklus. Tahap-tahap dalam penelitian ini yaitu: perencanaan, pelaksanaan, observasi dan refleksi. Subjek dalam penelitian ini adalah guru sebagai peneliti dan anak Kelompok B TK Mekar Indah Kota Kendari yang berjumlah 18 orang anak. Hasil penelitian ini menunjukkan bahwa kemampuan motorik halus anak melalui kegiatan Mewarnai, Menggunting dan Menempel (3M) menunjukkan bahwa terdapat peningkatan. Pada siklus I diperoleh persentase ketercapaian $77,78 \%$ dan pada siklus II mengalami peningkatan diperoleh persentase ketercapaian sebesar $88,89 \%$. Dengan demikian, dapat disimpulkan bahwa kemampuan motorik halus anak dapat ditingkatkan melalui kegiatan Mewarnai, Menggunting, dan Menempel (3M) pada TK Mekar Indah Kota Kendari.
\end{abstract}

Kata kunci: Mewarnai, Menggunting, Menempel.

\section{THE INCREASED OF CHILDREN FINE MOTOR ABILITY THROUGH COLORING, CUTTING AND PASTING (3 KIND ACTIVITIES) IN TK INDAH MEKAR KENDARI CITY}

\begin{abstract}
The research aimed to increased the children fine motor ability through coloring, cutting and pasting ( 3 kind activities) in TK Indah Mekar Kendari City. This research is the Classroom Action Research that conducted in two cycles. The procedure this research that: planning, implementation, observation, and reflection. The subjects in this study were teachers and chidrens in group B TK Indah Mekar Kendari City which obtained of 18 people. The result of the research that children fine motor ability through coloring, cutting and pasting (3 kind activities) showed the achieved. In the first cycle obtained by percentage completeness obtained $77,78 \%$ and the second cycle percentage of obtained completeness $88,89 \%$. The research concluded that the children fine motor ability can be increased through coloring, cutting and pasting (3 kind activities) in TK Indah Mekar Kendari City.
\end{abstract}

Keywords: Coloring, Cutting, Pasting

\section{PENDAHULUAN}

Kemampuan fisik motorik sangat penting untuk menunjang kelangsungan hidup seharihari oleh karena itu kemampuan fisik motorik anak usia dini harus dikembangkan sejak usia dini baik kemampuan motorik kasar maupun kemampuan motorik halus. Aktivitas keterampilan motorik halus anak Taman Kanak- kanak bertujuan untuk melatih keterampilan koordinasi motorik anak diantaranya koordinasi antara tangan dan mata yang dapat dikembangkan melalui kegiatan bermain (Sumantri, 2005: 145).

Sujiono (2008: 1.14) mengungkapkan motorik halus adalah gerakan yang melibatkan bagian- bagian tubuh tertentu saja dan dilakukan oleh otot-otot kecil, seperti keterampilan 
menggunakan jari-jemari tangan dan gerakan pergelangan tangan yang tepat. Menurut Rosmala (2005: 2) motorik halus merupakan keterampilan yang menggunakan jari jemari, tangan dan gerakan pergelangan tangan dengan tepat.

Mutahir, Toho dan Gusril (2004: 51) menyatakan bahwa fungsi utama motorik halus ialah mengembangkan kesanggupan dan keterampilan setiap individu yang berguna untuk mempertinggi daya kerja. Lebih lanjut dijelaskan bahwa dengan mempunyai keterampilan motorik yang baik, tentu individu mempunyai landasan untuk menguasai tugas keterampilan yang khusus.

Berdasarkan observasi awal yang dilakukan di TK Mekar Indah mengenai kemampuan motorik halus ketika kegiatan Mewarnai, Menggunting dan Menempel (3M) masih sangat rendah. Dari 18 anak yang terdiri dari 11 anak laki-laki dan 7 anak perempuan, hanya $61,11 \%$ yang tercapai, dimana ada 3 anak yang mendapat nilai bintang (****) atau Berkembang Sangat Baik (BSB) dan 8 anak yang mendapat nilai bintang (***) atau Berkembang Sesuai Harapan (BSH). Kondisi ini tentunya perlu alternatif strategi pembelajaran agar kemampuan motorik halus anak dapar dikembangkan dengan baik. Salah satunya adalan kegiatan Mewarnai, Menggunting, dan Menempel (3M).

Pamadhi (2008) mengungkapkan bahwa kegiatan Mewarnai, Menggunting dan Menempel (3M) merupakan kegiatan yang mempunyai kaitan dengan kemampuankemampuan menggunakan alat serta melatih motorik halus anak karena motorik halus anak ini akan menjadi dasar kemampuan sensitive anak terhadap gejala-gejala yang melingkupi kehidupan anak baik masa anak maupun setelah dewasa.

Sumanto (2005: 65) bahwa kreativitas yang dapat dikembangkan pada kegiatan mewarnai bagi anak TK adalah adanya kebebasan untuk memilih dan mengkombinasikan unsur warna pada obyek yang diwarnainya sesuai keinginan anak. (Sujiono, 2008: 2.12) tujuan dari kegiatan mewarnai adalah melatih menggerakkan pergelangan tangan.

Suratno (2005: 126) menyatakan bahwa kegiatan menggunting membutuhkan proses keterampilan menggerakkan otot-otot tangan dan jari-jari untuk berkoordinasi dalam menggunting sehingga bisa memotong kertas, kain atau yang lain sesuai yang diinginkan; seperti menggunting yang berpola, menggunting dan melipat untuk membentuk gambar, membentuk pola ataupun yang lain.

Mukhtar (2013: 194) mengungkapkan tahapan perkembangan menggunting anak yaitu sebagai berikut:

1. Tahap pra menggunting

Kegiatan yang memperkuat tangan dan genggaman harus dimulai sejak bayi dengan kegiatan anak memungut benda-benda kecil, kegiatan meremas, kegiatan merobek dengan sepenuh tangan dan kegiatan merobek dengan jari.

2. Perkembangan menggunting

Adapun tahapan-tahapan kegiatan menggunting yang dapat dilakukan bagi anak adalah: (a) tahap ke-1 : menggunting sekitar pinggiran kertas, (b) tahap ke-2 : menggunting dengan sepenuh bukaan gunting, (c) tahap ke-3: membuka dan menggunting terus menerus untuk sepanjang kertas, (d) tahap ke-4 : menggunting di antara dua garis lurus, (e) tahap ke-5 : menggunting bentuk tetapi tidak pada garis, (f) tahap ke-6 : menggunting pada garis tebal dengan terkendali, (g) tahap ke-7 : Menggunting bermacam-macam bentuk.

Menggunting melatih anak agar mampu menggunakan alat dan melatih keterampilan memotong objek gambar. Menggunting akan membantu perkembangan motorik anak karena dengan kegiatan menggunting yang tepat, memilih dimana yang harus digunting merupakan latihan motorik dan keterampilan bagi anak (Pamadhi, 2008). Begitu juga dengan kegiatan menempel, membuka perekat lalu menempelkan ditempat yang sudah ditentukan membuat jari jemari anak lebih terlatih. Gerakan halus yang dilakukan anak saat berlatih menggunting dan menempel kelak akan membantu anak lebih mudah belajar menulis.

\section{METODE}

Jenis penelitian ini termaksud dalam jenis Penelitian Tindakan Kelas (PTK) yakni adanya tindakan- tindakan tertentu untuk memperbaiki proses belajar mengajar. Menurut Iskandar (2011: 20) PTK merupakan bagian dari penelitian tindakan (action research) yang dilakukan oleh guru dan dosen di kelas (sekolah dan perguruan tinggi) tempat ia mengajar yang bertujuan memperbaiki dan meningkatkan kualitas dan kuantitas proses pembelajaran di kelas. 
Penelitian ini bertempat di Kelompok B TK Mekar Indah Kota Kendari. Subjek dalam penelitian ini adalah guru dan anak didik di TK Mekar Indah Kelompok B 1.2 yang berjumlah 18 orang terdiri atas 7 orang anak perempuan dan 11 orang anak laki-laki.

Adapun faktor-faktor yang diteliti dan diamati dalam penelitian ini adalah sebagai berikut: (1) faktor guru, mengamati aktivitas guru dalam penerapan kegiatan Mewarnai, Menggunting dan Menempel (3M) untuk meningkatkan kemampuan motorik halus anak di Kelompok B TK Mekar Indah Kota Kendari, (2) faktor anak, mengamati aktivitas anak dalam mengikuti kegiatan pembelajaran dengan menggunakan kegiatan Mewarnai, Menggunting dan Menempel (3M), (3) hasil belajar anak tentang penggunaan kegiatan $3 \mathrm{M}$.

Prosedur pelaksanaan dalam penelitian ini terdiri dari dua siklus dan masing-masing siklus memuat tiga kali pertemuan dalam satu minggu. Desain yang akan digunakan dalam penelitian ini ada empat tahapan yang dilalui, yakni: perencanaan, pelaksanaan, observasi dan refleksi (Dimyati, 2013: 122).

Teknik dalam pengumpulan data yang digunakan pada pelaksanaan penelitian ini adalah sebagai berikut: (1) observasi adalah suatu teknik yang dapat dilakukan guru untuk mendapatkan berbagai informasi atau data tentang perkembangan dan permasalahan anak, (2) wawancara merupakan pengumpulan data dengan jalan atau cara berdialog langsung dengan para responden secara lisan berdasarkan hasil pengamatan di kelas selama proses belajar mengajar, (3) dokumentasi untuk memperoleh data dengan melihat kondisi nyata di lapangan dalam hal ini di dalam kelas saat proses pelaksanaan pembelajaran dengan menggunakan media kartu angka.

Pengelolaan data dalam penelitian ini disesuaikan dengan teknik penilaian di TK Mekar Indah Kota Kendari yaitu dengan menggunakan tanda sebagai berikut: * = Belum Berkembang $(\mathrm{BB}), \quad * *=$ Mulai Berkembang $(\mathrm{MB}), \quad * * *=$ Berkembang Sesuai Harapan $(\mathrm{BSH})$, dan $* * * *=$ Berkembang Sangan Baik (BSB) (Depdiknas, 2004: 26).

Indikator kinerja untuk mengetahui keberhasilan dalam penelitian tindakan kelas ini dipergunakan kriteria keberhasilan yaitu dari segi proses, tindakan dikatakan berhasil apabila hasil observasi terhadap guru dan anak telah telah mencapai persentase $75 \%$ sesuai dengan skenario pembelajaran. Dari segi hasil, apabila
$75 \%$ anak memperoleh nilai $\geq * * *$ maka kemampuan motorik halus anak melelui kegiatan Mewarnai, Menggunting dan Menempel (3M) dapat dikatakan berhasil.

\section{HASIL DAN PEMBAHASAN}

Berdasarkan hasil observasi awal sebelum pelaksanaan tindakan penelitian, kemampuan motorik halus pada anak kelompok B 1.2 TK Mekar Indah Kota Kendari diasumsikan bahwa secara klasikal belum ada peningkatan pada kemampuan motorik halus anak. Saat terakhir penilaian, rata-rata anak memiliki perolehan nilai bintang $(* *)$ atau Mulai Berkembang (MB) yang diperoleh oleh 6 orang anak didik atau sebesar 33\% dengan kata lain sebagian besar anak didik belum mampu memenuhi target ketercapaian dalam indikator keberhasilan dalam kegiatan penilaian sehingga hal ini perlu diberikan bantuan secara langsung dan bimbingan secara menyeluruh pada kegiatan tersebut. Tampak juga ada 8 orang anak didik yang memperoleh bintang $(* * *)$ atau Berkembang Sesuai Harapan (BSH) atau sebesar $44 \%$ dan 3 orang anak didik yang memperoleh nilai bintang $(* * * *)$ atau Berkembang Sangat Baik (BSB) atau sebesar 16\% namun terdapat 1 orang anak didik yang memperoleh nilai bintang (*) atau Belum Berkembang (BB) atau sebesar $7 \%$.

Selajutnya peneliti akan berdiskusi kembali dengan guru kelompok B 1.2 untuk menerapkan kegiatan pembelajaran dalam rangka meningkatkan kemampuan motorik halus anak melalui kegiatan Mewarnai, Menggunting dan Menempel (3M) pada tindakan siklus I.

Hasil observasi mengajar guru sesuai dengan pedoman lembar obsevasi sebanyak 14 aspek yang diamati akan dicapai oleh guru. Pada siklus I skor yang dicapai oleh guru dari 14 aspek hanya 9 aspek setara dengan 64,28\%. Aspek yang diamati diantaranya yaitu: (1) guru menyampaikan tujuan pembelajaran, melakukan apersepsi dengan tema/subtema yaitu binatang/binatang yang hidup di darat, (3) guru menyiapkan alat dan bahan pembelajaran, (4) guru menjelaskan kepada anak cara memegang pensil dengan benar, (5) guru memberikan contoh cara mewarnai pola gambar dengan rapi, (6) guru menjelaskan kepada anak cara memegang gunting dengan benar, (7) guru memberikan contoh cara menggunting sesuai pola gambar, (8) guru memberikan contoh cara menempel gambar sesuai pola dengan baik dan 
rapi, (9) guru mempersilahkan kepada anak untuk melakukan kegiatan Mewarnai, Menggunting dan Menempel (3M), (10) guru memantau anak dengan berkeliling dalam kelas saat anak sedang melakukan kegiatan pembelajaran, (11) guru memberikan bimbingan kepada anak dalam kegiatan Mewarnai, Menggunting dan Menempel (3M), (12) guru mengadakan tanya jawab mengenai kegiatan yang dilakukan (13) guru memberikan motivasi dan penghargaan pada anak, (14) memberikan kesimpulan terhadap kegiatan yang dilakukan. Aspek yang tidak tercapai sebanyak 5 aspek dengan persentase $35,72 \%$.

Pada siklus I, aktivitas belajar anak yang diamati menggunakan lembar observasi aktivitas belajar anak terdiri atas 14 aspek. Analisis hasil aktivitas belajar anak pada 14 aspek yang diamati dan harus dicapai oleh anak. Pada siklus I persentase aspek yang diamati mencapai 78,58\% dengan rincian 14 aspek hanya 11 aspek yang dilaksanakan. Aspek yang diamati diantaranya yaitu: (1) anak mendengarkan guru menyampaikan tujuan pembelajaran, (2) aktif pada kegiatan apersepsi, (3) memperhatikan guru saat memperkenalkan media pembelaran, (4) anak memperhatikan guru menjelaskan cara memegang pensil dengan benar, (5) anak memperhatikan guru saat memberikan contoh cara mewarnai pola gambar dengan rapi (6) anak memperhatikan guru menjelaskan cara memegang gunting dengan benar (7) anak memperhatikan guru saat memberikan contoh cara menggunting sesuai pola gambar, (8) anak memperhatikan guru saat memberikan contoh cara menempel gambar sesuai pola dengan baik dan rapi, (9) anak antusias bertanya, (10) anak melakukan kegiatan Mewarnai, Menggunting dan Menempel (3M) dengan rapi, baik dan benar, (11) anak mendapatkan bimbingan dari guru dalam kegiatan yang dilakukan, (12) melakukan tanya jawab dengan guru tentang kegiatan yang dilakukan, (13) mendengarkan nasehat dan kesimpulan terhadap kegiatan yang dilakukan, (14) anak menyanyikan lagu yang berhubungan dengan binatang. Aspek yang tidak tercapai sebanyak 3 aspek dengan persentase 21,42\% yaitu: anak belum mendengarkan guru menyampaikan tujuan pembelajaran, anak tidak melakukan tanya jawab dengan guru tentang kegiatan yang dilakukan dan anak belum mendengarkan nasehat dan kesimpulan terhadap kegiatan yang dilakukan, yaitu: guru menyampaikan tujuan pembelajaran, guru menjelaskan cara memegang pensil yang benar, guru mengadakan tanya jawab mengenai kegiatan yang dilakukan hari ini, guru memberikan motivasi dan penghargaan pada anak dan guru memberikan kesimpulan terhadap kegiatan yang dilakukan hari ini.

Hasil analisis observasi guru sesuai dengan lembar observasi sebanyak 14 aspek yang harus dicapai oleh guru. Pada siklus II persentase aspek yang diamati mencapai $92,86 \%$ dengan rincian dari 14 aspek hanya 13 aspek yang dilaksanakan. Aspek yang diamati diantaranya yaitu: (1) anak mendengarkan guru menyampaikan tujuan pembelajaran, (2) aktif pada kegiatan apersepsi, (3) memperhatikan guru saat memperkenalkan media pembelajaran, (4) anak memperhatikan guru menjelaskan cara memegang pensil dengan benar, (5) anak memperhatikan guru saat memberikan contoh cara mewarnai pola gambar dengan rapi, (6) anak memperhatikan guru menjelaskan cara memegang gunting dengan benar, (7) anak memperhatikan guru saat memberikan contoh cara menggunting sesuai pola gambar, (8) anak memperhatikan guru saat memberikan contoh cara menempel gambar sesuai pola dengan baik dan rapi, (9) anak antusias bertanya, (10) anak melakukan kegiatan Mewarnai, Menggunting dan Menempel (3M) dengan rapi, baik dan benar, (11) anak mendapatkan bimbingan dari guru dalam kegiatan yang dilakukan, (12) melakukan tanya jawab dengan guru tentang kegiatan yang dilakukan, (13) mendengarkan nasehat dan kesimpulan terhadap kegiatan yang dilakukan, (14) anak menyanyikan lagu yang berhubungan dengan binatang. Aspek yang tidak tercapai sebanyak 1 aspek dengan persentase $7,14 \%$ yaitu guru memberikan motivasi dan penghargaan pada anak.

Hasil analisis aktivitas belajar anak sesuai dengan lembar observasi pada siklus II sebanyak 14 aspek yang diamati diharapkan dapat tercapai, namun yang tercapai sebanyak 12 aspek $(85,71 \%)$, aspek yang diamati diantaranya: (1) anak mendengarkan guru menyampaikan tujuan pembelajaran, (2) aktif pada kegiatan apersepsi, (3) memperhatikan guru saat memperkenalkan media pembelaran, (4) anak memperhatikan guru menjelaskan cara memegang pensil dengan benar, (5) anak memperhatikan guru saat memberikan contoh cara mewarnai pola gambar dengan rapi, (6) anak memperhatikan guru menjelaskan cara memegang gunting dengan benar, (7) anak memperhatikan guru saat memberikan contoh 
cara menggunting sesuai pola gambar, (8) anak memperhatikan guru saat memberikan contoh cara menempel gambar sesuai pola dengan baik dan rapi, (9) anak antusias bertanya, (10) anak melakukan kegiatan Mewarnai, Menggunting dan Menempel (3M) dengan rapi, baik dan benar, (11) anak mendapatkan bimbingan dari guru dalam kegiatan yang dilakukan, (12) melakukan tanya jawab dengan guru tentang kegiatan yang dilakukan, (13) mendengarkan nasehat dan kesimpulan terhadap kegiatan yang dilakukan, (14) anak menyanyikan lagu yang berhubungan dengan binatang. Aspek yang tidak tercapai sebanyak 2 aspek dengan persentase $14,29 \%$.

Berdasarkan hasil penelitian yang dilakukan di TK Mekar Indah Kota Kendari pada kelompok B selama dua siklus, terdapat peningkatan kemampuan moorik halus anak. Hal ini dapat terlihat oleh kemampuan motorik halus anak pada saat hasil observasi awal sebelum tindakan sebesar $61,11 \%$, pada siklus I meningkat menjadi $72,22 \%$ dan pada siklus II lebih meningkat lagi menjadi $88,89 \%$. Dengan demikian maka dapat disimpulkan bahwa kemampuan motorik halus dapat ditingkatkan melalaui kegiatan Mewarnai, Menggunting dan Menempel (3M).

\section{KESIMPULAN DAN SARAN}

Berdasarkan hasil dan pembahasan dalam penelitian ini maka dapat disimpulkan bahwa kemampuan motorik halus dapat ditingkatkan melalaui kegiatan Mewarnai, Menggunting dan Menempel (3M).

Saran yang dapat dikemukakan dari hasil penelitian ini yaitu sebaiknya guru menggunakan kegiatan Mewarnai, Menggunting dan Menempel (3M) sebagai salah satu cara untuk meningkatkan motorik halus anak karena dari hasil penelitian terbukti bahwa melalui kegiatan Mewarnai, Menggunting dan Menempel (3M) dapat meningkatkan motorik halus anak.

\section{DAFTAR PUSTAKA}

Depdiknas. 2004. Pedoman Penilaian di Taman Kanak-Kanak. Jakarta: Depdiknas.

Dimyati, Johni. 2013. Metode Penelitian Pendidikan dan Aplikasinya Pada Pendidikan Anak Usia Dini. Jakarta. Kencana Prenada media Grup.
Iskandar, 2009. Penelitian Tindakan Kelas. Ciputat: Gaung Persada (GP) Pres

Mukhtar, Latif, dkk. 2013. Orientasi Baru Pendidikan Anak Usia Dini: Teori Dan Aplikasi. Jakarta: Kencana.

Mutahir, Cholik Toho dan Gusril. 2004. Perkembangan Motorik Pada Masa Anak-anak. Jakarta: Depdikbud.

Pamadhi, Hajar. 2008. Materi Pokok Seni Keterampilan Anak. Jakarta: PT Rineka Cipta.

Rosmala, Dewi. 2005. Berbagai Masalah Anak Taman Kanak-Kanak. Jakarta: Departemen Pendidikan Nasional.

Sujiono, Bambang. 2008. Metode Pengembangan Fisik . Jakarta: Universitas Terbuka.

Sumanto. 2005. Pengembangan Kreativitas Seni Rupa Anak TK. Jakarta: Departemen Pendidikan Nasional.

Sumantri. 2005. Pengembangan Keterampilan Motorik Anak Usia Dini. Jakarta: Dinas Pendidikan.

Suratno. 2005. Pengembangan Kreativitas Anak Usia Dini. Jakarta: Depdiknas. 